\title{
Decadal changes in glacier parameters in the Cordillera Blanca, Peru, derived from remote sensing
}

\author{
Adina E. RACOVITEANU, ${ }^{1,2,3}$ Yves ARNAUD, ${ }^{4}$ Mark W. WILLIAMS, ${ }^{1,2}$ \\ Julio ORDOÑEZ ${ }^{5}$ \\ ${ }^{1}$ Department of Geography, University of Colorado, Boulder, Colorado 80309-0260, USA \\ E-mail: racovite@colorado.edu \\ ${ }^{2}$ Institute of Arctic and Alpine Research, University of Colorado, Boulder, Colorado 80309-0450, USA \\ ${ }^{3}$ National Snow and Ice Data Center/World Data Center for Glaciology, CIRES, University of Colorado, Boulder, \\ Colorado 80309-0449, USA \\ ${ }^{4} I R D$, Great Ice, Laboratoire de Glaciologie et Géophysique de I'Environnement du CNRS \\ (associé à I'Université Joseph Fourier-Grenoble I), 54 rue Molière, BP 96, 38402 Saint-Martin-d'Hères Cedex, France \\ ${ }^{5}$ Direcion de Hidrología y Recursos Hidricos, \\ Servicio Nacional de Meteorología e Hidrología Jirón Cahuide No. 175 - Jesús María, Lima 11, Peru
}

\begin{abstract}
We present spatial patterns of glacier fluctuations from the Cordillera Blanca, Peru, (glacier area, terminus elevations, median elevations and hypsography) at decadal timescales derived from 1970 aerial photography, 2003 SPOT5 satellite data, Geographic Information Systems (GIS) and statistical analyses. We derived new glacier outlines from the 2003 SPOT images, and ingested them in the Global Land and Ice Measurements from Space (GLIMS) glacier database. We examined changes in glacier area on the eastern and western side of the Cordillera in relation to topographic and climate variables (temperature and precipitation). Results include (1) an estimated glacierized area of $569.6 \pm 21 \mathrm{~km}^{2}$ in 2003 , (2) an overall loss in glacierized area of $22.4 \%$ from 1970 to 2003 , (3) an average rise in glacier terminus elevations by $113 \mathrm{~m}$ and an average rise in the median elevation of glaciers by $66 \mathrm{~m}$, showing a shift of ice to higher elevations, especially on the eastern side of the Cordillera, and (4) an increase in the number of glaciers, which indicates disintegration of ice bodies. Annual air temperature showed a significant upward trend in the last 30 years, with larger temperature increases at lower elevations. There was a slight but not significant decrease in precipitation. Our results are consistent with glacier retreat and warming trends noted in the last three decades in the tropics.
\end{abstract}

\section{INTRODUCTION}

Multitemporal satellite imagery and older aerial photography have been used extensively in the last decade to quantify glacier changes in mountainous areas throughout the world, including Patagonia (Aniya and others, 1996), the Swiss Alps (Kääb and others, 2002; Paul and others, 2002), central Asia (Khromova and others, 2003, 2006; Surazakov and Aizen, 2006; Aizen and others, 2007; Bolch, 2007), the Peruvian Andes (Georges, 2004; Silverio and Jaquet, 2005) and the Himalaya (Kulkarni and Bahuguna, 2002; Kulkarni and others, 2005). More recently, satellite images have been used to estimate glacier mass balances and equilibrium-line altitudes (ELAs) (Khalsa and others, 2004; Rabatel and others, 2005; Berthier and others, 2007). There is continued interest in mapping the world's glaciers using satellite data. The Global Land and Ice Measurements from Space (GLIMS) project was initiated with the goal of mapping the world's glaciers using satellite imagery (Kargel and others, 2005). Remote-sensing methods are useful for detecting glacier changes in a timely manner in remote regions where traditional field-based glaciological methods are limited by difficult logistics and lack of support.

Tropical glaciers of the Cordillera Blanca, Peru, are of interest for several reasons. At local scales, glacier runoff constitutes the main water source for hydropower generation, irrigation for agriculture use, and domestic or animal consumption. Rapid melting of Andean glaciers in recent decades (Kaser and others, 2003) poses a threat to local water resources. There is also concern about glacier-related hazards such as glacier lake outburst floods (GLOFs) associated with moraine-dammed lakes. An extensive glacier inventory for the Cordillera Blanca was compiled on the basis of 1970 aerial photography (Ames and others, 1989). More recent Landsat Thematic Mapper (TM) and Système Probatoire pour l'Observation de la Terre (SPOT) satellite imagery was used to estimate changes in glacier extents at different time-steps (Kaser and others, 1996; Georges, 2004; Silverio and Jaquet, 2005). Glacier lengths and mass balance have been reported for a limited number of glaciers with field measurements (Hasternath and Ames, 1995; Ames and Hasternath, 1996). However, there remains a paucity of information on glacier parameters such as glacier area, length, terminus elevations, hypsography, ELA, accumulation-area ratio (AAR), mass balance and hypsometry, due to a lack of reliable elevation data from which these parameters can be extracted. Furthermore, the relationship between glacier parameters and glacier area changes has not been investigated thoroughly in the Cordillera Blanca. Only one study (Mark and Seltzer, 2005) evaluated the spatial distribution of glacier fluctuations with respect to climate forcing in the Andes.

The availability of new remote-sensing platforms with high spatial and temporal resolution, global coverage and reasonable financial costs provides the potential to evaluate glacier parameters in remote areas such as the Andes. Updated glacier parameters are needed to assess spatial patterns of glacier changes and their connections with 


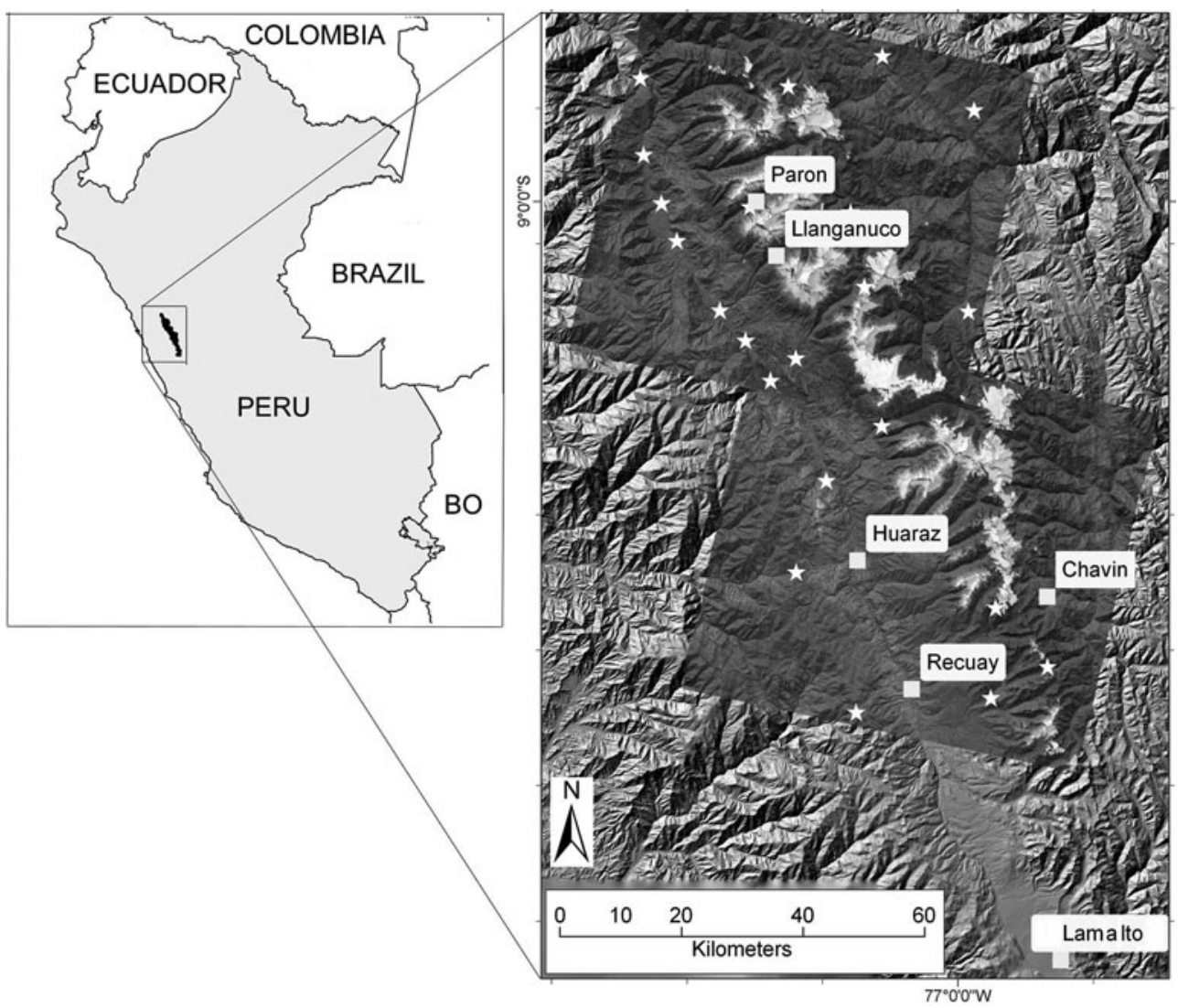

Fig. 1. Cordillera Blanca study area. Spatial domain 1 is the area covered by the two orthorectified SPOT scenes from August 2003 . Also shown are ground-control points acquired in the field (white stars), and climate stations with complete 30 year temperature and precipitation records (white squares).

climate fluctuations at local and regional scales. This study combines data from SPOT with field measurements and Geographic Information Systems (GIS) to understand spatial patterns of glacier fluctuations in the Cordillera Blanca at decadal scales. Specific objectives include (1) estimating the glacierized area in 2003, (2) estimating changes in glacier area from 1970 to 2003, (3) estimating changes in the elevations of glacier termini over the same time-span, (4) quantifying hypsometry changes and (5) evaluating airtemperature and precipitation trends in the last 30 years.

\section{STUDY AREA}

The study area is the Peruvian Cordillera Blanca (Fig. 1), the largest glacierized area in the tropics, stretching $180 \mathrm{~km}$ north-south between $8^{\circ} 30^{\prime} \mathrm{S}$ and $10^{\circ} \mathrm{S}$ (Kaser and others, 1990). The glacierized area was estimated to be $723.37 \mathrm{~km}^{2}$ based on 1970 aerial photography, with an average thickness of $31.25 \mathrm{~m}$ (Ames and others, 1989). The Cordillera Blanca comprises valley glaciers with elevations ranging from $\sim 3000$ to $\sim 6800 \mathrm{~m}$ and very steep slopes. Some of the glacier tongues are covered with debris, and many of them terminate at moraine-impounded glacier lakes. Climatically, the Cordillera Blanca is situated in the outer tropics, characterized by an absence of thermal seasonality and a distinct seasonality of precipitation, with one distinguishable wet season (austral summer) and one dry season (winter) (Kaser and Osmaston, 2002). Snow accumulation occurs during the wet season, and there is relatively little accumulation in the dry season. Ablation occurs yearround, with higher rates in the wet season (Kaser and
Osmaston, 2002). Southeasterly winds bring precipitation from the Amazon basin, making the windward (eastern) side of the cordillera two to three times wetter than the leeward (western) side (Johnson, 1976).

\section{METHODS}

\section{Data sources}

The baseline dataset for this study was the 1970 glacier inventory for the Cordillera Blanca, constructed from aerial photography and published by Ames and others (1989). We obtained the digital version of the inventory from Unidad de Glaciología y Recursos Hídricos (UGRH) of Instituto Nacional de Recursos Naturales Ancash (INRENA), Peru. In 2004, we acquired 24 ground-control points (GCPs) on non-glaciated terrain (road intersections, curves and buildings visible on the satellite images) using an Ashtech ProMark2 differential global positioning system (DGPS). The horizontal and vertical accuracy of the GPS points after post-processing was $<1 \mathrm{~m}$. These GCPs were used for orthorectification of the satellite scenes and validation of the digital elevation data. We constructed a digital elevation model (DEM) with $30 \mathrm{~m}$ cell size by interpolating contour lines digitized from two $1: 100000$ topographic maps based on 1970 aerial photography, using the TOPOGRID algorithm (Burrough and McDonnell, 1998). We denote this DEM as the '1970 DEM'. The methodology was tested at a different site in Peru and was found to yield satisfactory results (Racoviteanu and others, 2007). We estimate the horizontal accuracy of the DEM to be less than half the contour interval 
Table 1. Climate stations with complete records from 1970 to 1999 (Fig. 1), with parameters measured, and the total change over the 30 year period. Temperature and precipitation trends for the 1970-99 period for the different elevations are based on the Mann-Kendall nonparametric test

\begin{tabular}{|c|c|c|c|c|c|c|}
\hline \multirow{3}{*}{ Name } & \multicolumn{2}{|c|}{ Climate station } & \multicolumn{4}{|c|}{ Mann-Kendall results } \\
\hline & Elevation & Parameter & $p$ value & $\Delta T$ & $\Delta P$ & Total change 1970-99 \\
\hline & $\mathrm{m}$ & & & ${ }^{\circ} \mathrm{Ca}^{-1}$ & $\mathrm{~mm} \mathrm{a}^{-1}$ & \\
\hline Huaraz & 3038 & Temperature & 0.00015 & 0.09 & - & $+2.79^{\circ} \mathrm{C}$ \\
\hline Recuay & 3394 & Temperature & 0.00043 & 0.05 & - & $+1.55^{\circ} \mathrm{C}$ \\
\hline Lamalto & 4030 & Temperature & 0.00008 & 0.03 & - & $+0.93^{\circ} \mathrm{C}$ \\
\hline Chavin & 3150 & Precipitation & 0.14854 & - & -5.92 & $-183.52 \mathrm{~mm}$ \\
\hline Llanganuco & 3800 & Precipitation & 0.75962 & - & 0.84 & $+26.04 \mathrm{~mm}$ \\
\hline Paron & 4100 & Precipitation & 0.69585 & - & -1.16 & $-35.96 \mathrm{~mm}$ \\
\hline
\end{tabular}

$(25 \mathrm{~m})$. Its vertical accuracy (root-mean-square error in the vertical coordinate $\left(\mathrm{RMSE}_{z}\right)$ with respect to the GCPs) is $18 \mathrm{~m}$. All the datasets were projected to Universal Transverse Mercator (UTM) zone 18S, with the World Geodetic System 1984 (WGS84) horizontal datum and the Earth Geopotential Model 1996 (EGM96) vertical datum.

The SPOT5 sensor launched in 2002 acquires data in multispectral and panchromatic mode, suitable for glaciological applications. Bands $1(0.50-0.59 \mu \mathrm{m})$ and $2(0.61-$ $0.68 \mu \mathrm{m})$ of SPOT5 are in the visible part of the electromagnetic spectrum (VIS), band $3(0.79-0.89 \mu \mathrm{m})$ is in the near-infrared (NIR) and band 4 is in the mid-infrared (MIR) $(1.58-1.75 \mu \mathrm{m})$. The spatial resolution of the sensor is $10 \mathrm{~m}$ for the VIS and NIR bands and $20 \mathrm{~m}$ for the MIR. Two scenes were needed to cover about $90 \%$ of the Cordillera Blanca. The scenes were acquired in August 2003, at the end of the dry season to ensure minimal snow cover, and had no cloud cover. The scenes were orthorectified using the field-based GCPs and the DEM using Toutin's model (Toutin and others, 2002). The horizontal root-mean-square error $\left(\operatorname{RMSE}_{x, y}\right)$ with respect to GCPs was $<5 \mathrm{~m}$ for both images, which is considered appropriate as it is half of the SPOT5 image pixel size.

Long-term changes in annual temperature and precipitation were evaluated from climate records provided by Servicio Nacional de Meteorología e Hidrología (SENHA$\mathrm{MI})$, Peru. Climate stations are located on the western side of the Cordillera Blanca; there are no long-term climate records from the eastern side (Fig. 1). We selected climate stations based on two criteria: (1) continuous and complete long-term records of 30 years, from 1970 to 1999; and (2) representation of an elevation gradient from 3000 to $>4000 \mathrm{~m}$ (Table 1). We evaluated the statistical significance of temperature and precipitation trends and determined the linear slopes for significant trends using the Mann-Kendall non-parameteric test (Del Río and others, 2007).

\section{Glacier delineation and analysis}

We tested various image classification techniques such as single-band ratios and ratio images with various band combinations, as well as unsupervised classification techniques (ISODATA) and supervised techniques (maximum likelihood classification). The normalized-difference snow index (NDSI) method (Hall and others, 1995) proved to be superior to other band combinations based on visual inspection of color composites. The NDSI is a robust, easily applied method and is less sensitive to illumination variations than non-ratio techniques. The technique is similar to the normalized-difference vegetation index (NDVI) used for vegetation mapping and is calculated as (VIS - NIR)/ (VIS + NIR). It takes advantage of the high brightness values of snow and ice in the visible wavelengths $(0.4-0.7 \mu \mathrm{m}) \mathrm{vs}$ low brightness value in the near and mid-infrared (0.75$1.75 \mu \mathrm{m})$ to separate them from darker areas such as rock, soil or vegetation. The NDSI is also useful to discriminate clouds if the 1.6-1.7 $\mu \mathrm{m}$ band is available (band 4 of SPOT), because at these wavelengths, clouds are reflective and snow/ice is absorbing (Dozier, 1984). Band 4 was resampled to $10 \mathrm{~m}$ to match the resolution of the visible bands, using a bilinear method. The resulting NDSI image with values from -1 to 1 was segmented using a threshold value of 0.5 to obtain a binary map of glacier/non-glacier areas. Debriscovered glaciers were digitized manually using a slope map derived from the DEM and a color composite map (SPOT 234). The raw ice polygons were visually checked for classification errors such as persistent seasonal snow, rock outcrops and moraines. Ice divides were computed using watershed delineation commands, following the protocol of Manley (in press). Resulting ice divides were visually inspected and refined manually, based on a shaded relief map constructed from the 1970 DEM.

To separate the ice mass into glaciers, we used the GLIMS definition of a 'glacier' tailored to remote sensing, compliant with the World Glacier Monitoring Service (WGMS) standards (B.H. Raup and S.J.S. Khalsa, http://www.glims. org/MapsAndDocs/assets/GLIMS_Analysis_Tutorial_a4.pdf). Under these standards, the bodies of ice above the bergschrund that are connected to the glacier are considered part of the glacier, as they contribute snow (through avalanches) and ice (through creep flow) to the glacier mass (Raup and Khalsa, http://www.glims.org/MapsAndDocs/assets/GLIMS_ Analysis_Tutorial_a4.pdf). We excluded exposed rock, including nunataks and snow-free steep rock walls, from the glacier area calculations. Each glacier was assigned an ID based on its geographic location (latitude and longitude coordinates). Glacier fragments that separated from a main 'parent' glacier from 1970 to 2003 were assigned a single ID of that parent glacier to facilitate subsequent comparison with the 1970 inventory. The resulting polygons were coded as 'internal rock', 'glacier boundary', 'proglacial lakes', 'supraglacial lakes' and 'debris boundary' following specifications of Raup and Khalsa (http://www.glims.org/ MapsAndDocs/assets/GLIMS_Analysis_Tutorial_a4.pdf). The accuracy of the SPOT-derived glacier outlines was computed 
Table 2. The spatial domains used for analysis, with their characteristics

Spatial domain No. Number of glaciers Description

3
485

367

571
Area covered by the two SPOT5 satellite images. Same as the area from Ames and others (1989), minus the Pongos, Caullaraju, Rosco and Pelegatos mountain groups, which were not covered by the SPOT scenes.

Subset of spatial domain 1. This includes glaciers whose ice divides matched in the old 1970 inventory and the SPOT-derived 2003 inventory.

The entire Cordillera Blanca area included in the IGN 1970 inventory (Ames and others, 1989). This includes the Pongos, Caullaraju, Rosco and Pelegatos mountain groups. using the 'Perkal epsilon band' and implemented as a buffer operation in vector GIS (Perkal, 1966; Burrough and McDonnell, 1998). This method was shown to slightly overestimate the error (Hoffman and others, 2007). Digitizing errors and 'sliver' polygons arising from overlay operations in mismatch areas (Burrough and McDonnell, 1998) were eliminated manually. Confusion between shadowed glacier areas and internal rocks was eliminated by comparing these areas against the high-quality 1:100000 Alpenvereinskarte Cordillera Blanca (Moser and others, 2000), to minimize classification errors. The SPOT5 glacier outlines were assigned positional accuracies and ingested in the GLIMS glacier database (http://nsidc.org/glims) maintained at the US National Snow and Ice Data Center (NSIDC) in Boulder (A.E. Racoviteanu and Y. Arnaud, http://www.glims.org).

The analysis of glacier changes was conducted at different spatial scales, so that we could compare our results with those of other investigators. The spatial domains, with their extents and characteristics, are shown in Table 2. Spatial domain 1 includes glaciers encompassed by the two SPOT scenes (Fig. 1). The two northernmost groups Rosco and Pelegatos) and two southernmost groups (Pongos and Caullaraju) were outside the two SPOT images and were not included in this domain. We first compared the 2003 SPOT-derived glacier outlines with the 1970 inventory for this domain to derive changes in glacier area, glacier terminus elevations and glacier median elevations. We constructed glacier hypsographies from the 1970 and 2003 outlines using elevations extracted from the 1970 DEM for

Table 3. Comparison of IGN 1970 and SPOT 2003 glacier inventories for spatial domain 1. Glacier elevations are based on the 1970 DEM for both the IGN 1970 and SPOT 2003 datasets

\begin{tabular}{lcccccc}
\hline \multirow{2}{*}{ Inventory/parameter } & \multicolumn{3}{c}{ IGN 1970} & \multicolumn{3}{c}{ SPOT 2003} \\
& Min. & Max. & Mean & Min. & Max. & Mean \\
& & & & & & \\
\hline Min $Z(\mathrm{~m})$ & 4127 & 5370 & 4750 & 4204 & 5369 & 4881 \\
Med $Z(\mathrm{~m})$ & 4328 & 5557 & 5086 & 4420 & 5695 & 5150 \\
Slope $\left(^{\circ}\right)$ & 13 & 48 & 31 & 12 & 52 & 32 \\
Aspect $\left({ }^{\circ}\right)$ & 0 & 359 & 187 & 0 & 359 & 193 \\
Area $\left(\mathrm{km}^{2}\right)$ & 0.03 & 18.44 & 1.48 & 0.006 & 16.17 & 1.07 \\
Number of glaciers & & 445 & & & 485 & \\
Total area $\left(\mathrm{km}^{2}\right)$ & $665.1^{*}$ & & & 516.1 & \\
Area change, $1970-2003(\%)$ & & -22.4 & &
\end{tabular}

*This area is different from that reported by Ames and others (1989), because for this study the IGN inventory was cropped to match the extent of spatial domain 1. both datasets. For each glacier in spatial domain 1, we calculated its area, terminus elevation, maximum elevation, median elevation, average slope angle and average aspect using grid-based modeling and zonal functions. Glaciers that broke into different parts were counted and analyzed as part of the same 'parent' glacier.

Spatial domain 2 is a subset of spatial domain 1 comprising 367 glaciers covering about $71 \%$ of the glacierized area, selected based on: (1) ice divides in 2003 matching closely those from the 1970 inventory; (2) glacier area greater than a cut-off value of $0.01 \mathrm{~km}^{2}$, which eliminated very small glaciers; and (3) minimal debris cover on glacier tongues. We investigated changes in glacier area from 1970 to 2003 and correlated these changes with glacier parameters using GIS methods and univariate statistics. The analysis of glaciers in spatial domain 1 was conducted separately for glaciers on the eastern and western sides of the Cordillera Blanca.

Spatial domain 3 is the total glacierized area covered by the 1970 Institut Géographique National (France) (IGN) inventory (Ames and others, 1989), and corresponds to our spatial domain 1 plus the four mountain groups at the northern and southern edges of the SPOT scenes (Fig. 1). To estimate the area of those glaciers outside the SPOT imagery in 2003, we used the recession technique developed by Kaser and others (1996) and Georges (2004). The overall factor of recession calculated as Area $_{2003} /$ Area $_{1970}$ was derived from spatial domain 1 and applied to the missing mountain groups.

\section{RESULTS AND DISCUSSION}

\section{The SPOT5 glacier inventory: spatial domain 1}

The classification of the two SPOT5 satellite images in 2003 yielded 485 glaciers, covering an area of $516.1 \mathrm{~km}^{2}$. Out of these, 57 glaciers had debris-covered tongues, totaling an area of $14.9 \mathrm{~km}^{2}$, which is $3 \%$ of the total glacierized area.

Table 4. Comparison of glacier parameters on the eastern vs the western side of the Cordillera Blanca (CB) for the glaciers in spatial domain 1

\begin{tabular}{lccccc}
\hline SPOT 2003 & $\begin{array}{c}\text { Slope } \\
\circ\end{array}$ & $\begin{array}{c}\text { Min } Z \\
\mathrm{~m}\end{array}$ & $\begin{array}{c}\text { Med } Z \\
\mathrm{~m}\end{array}$ & $\begin{array}{c}\text { Aspect } \\
\circ\end{array}$ & $\begin{array}{c}\text { Area } \\
\mathrm{km}^{2}\end{array}$ \\
\hline Western CB & 32 & 4914 & 5188 & 210 & 1.06 \\
Eastern CB & 32 & 4812 & 5072 & 156 & 1.09 \\
\hline
\end{tabular}




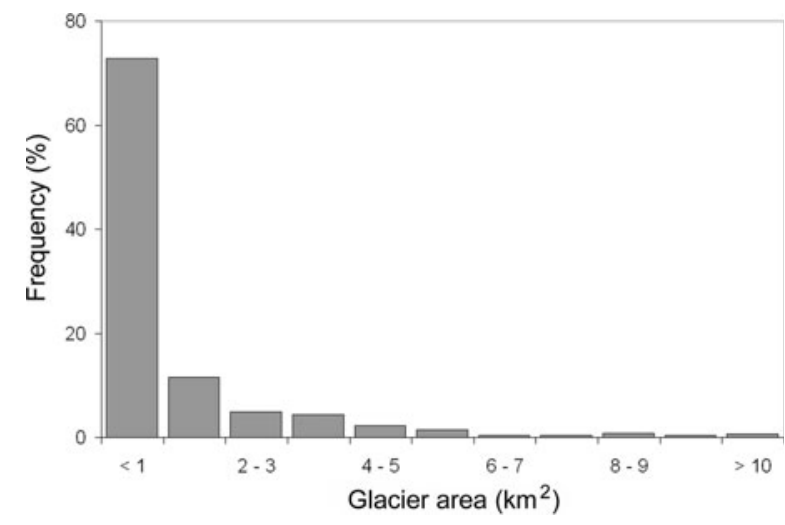

Fig. 2. Area frequency distribution of the 485 glaciers in spatial domain 1 of the Cordillera Blanca, derived from the analysis of SPOT5 images. Glaciers smaller than $1 \mathrm{~km}^{2}$ are prevalent in this area.

Descriptive statistics for the 485 glaciers derived from SPOT imagery are presented in Table 3. Elevations of the glacier termini range from 4204 to $5369 \mathrm{~m}$, with a mean of $4881 \mathrm{~m}$. On average, glacier termini are $102 \mathrm{~m}$ higher on the western slope of the Cordillera Blanca (4914 m) than on the eastern slope (4812 m) (Table 4). The median elevation of glaciers in spatial domain 1 ranges from 4420 to $5695 \mathrm{~m}$, with an average of $5150 \mathrm{~m}$ (Table 3). Glaciers on the western side of the Cordillera Blanca have median elevations $116 \mathrm{~m}$ higher than those on the eastern side (Table 4). The median elevation of glaciers decreases from southwest to northeast, a trend represented by a tilted surface, oriented towards the northeast. This southeast-northwest trend in glacier termini and median elevation reflects the orographic effect of the Cordillera Blanca, and is consistent with the regional gradient noted in previous studies (Kaser and Georges, 1997). On the eastern side, increased precipitation due to orographic uplift from the Amazon basin favors the extension of glacier termini to lower elevations and induces lower ELAs (Kaser and Georges, 1997).

SPOT-derived glaciers range in size from 0.006 to $16.17 \mathrm{~km}^{2}$, with a mean size of $1.07 \mathrm{~km}^{2}$ (Table 3). There are only five glaciers with area smaller than $0.01 \mathrm{~km}^{2}$, which are remnants of larger glaciers. The frequency histogram of glacier area (Fig. 2) shows the non-linear decrease in the number of glaciers with glacier size, suggesting that small glaciers $\left(<1 \mathrm{~km}^{2}\right)$ are much more common than large glaciers $\left(>10 \mathrm{~km}^{2}\right)$. For example, $73 \%$ of glaciers are smaller than $1 \mathrm{~km}^{2}$, and $48 \%$ of glaciers are smaller than $0.3 \mathrm{~km}^{2}$. The Cordillera Blanca may be particularly sensitive to small changes in climate because of the large number of small glaciers.

On average, glaciers on the eastern side of the Cordillera are slightly larger than those on the western side (Table 4). There is a negative correlation between terminus elevation and glacier area $(r=-0.6)$ : larger glaciers tend to extend down to lower elevations, while smaller glaciers have higher termini. These patterns were observed in other glacier areas (e.g. Alaska Brooks Range (Manley, in press) and the Swiss glaciers (Kääb and others, 2002)).

The average slope of the glaciers in spatial domain 1 is $32^{\circ}$ (Table 3), with an almost normal distribution (Fig. 3). The average glacier orientation is $193^{\circ}$ (southwest) (Table 3), with $32 \%$ of the glaciers oriented towards the south and southwest (Fig. 4). These results are similar to the Ames and

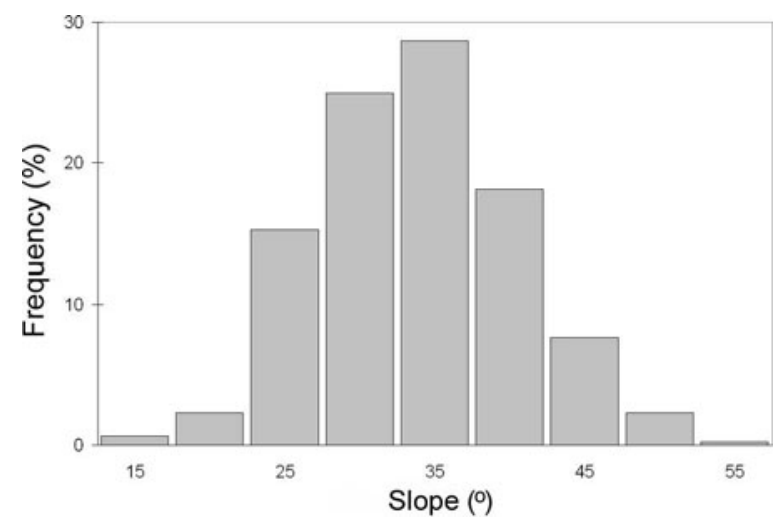

Fig. 3. Slope frequency distribution of the 485 glaciers in spatial domain 1. On average, glaciers in this area are steep, with a mean slope of $32^{\circ}$.

others (1989) inventory from 1970, which reported an average orientation of $187^{\circ}$ (Table 3 ). In the outer tropics of the Southern Hemisphere, these aspects are more shaded in the day during the wet (accumulation) season (Mark and Seltzer, 2005). Hence, the net energy balance is likely lower on southwest-facing aspects during the wet season, favoring precipitation as snow compared to rain, and reducing ablation from sublimation and melt.

The comparison of glacier statistics for the 1970 and 2003 inventories (Table 3) points to some changes in glacier parameters in spatial domain 1. The digital version of the 1970 IGN inventory covered an area of $665.1 \mathrm{~km}^{2}$. The SPOT-derived glacier area was $516.1 \mathrm{~km}^{2}$ in 2003 , indicating a loss in glacier area of $\sim 22.4 \%$ in 33 years $\left(0.68 \% \mathrm{a}^{-1}\right)$. The average glacier size decreased by about $0.4 \mathrm{~km}^{2}$ from 1970 to 2003 (Table 3). At the same time, the number of glaciers increased from 445 in the IGN inventory to 485 in the SPOT inventory, perhaps due to the disintegration of ice bodies. Similar fragmentation trends have been reported from other glacierized areas of the world (Paul and others, 2004; Kulkarni and others, 2007) and have been associated with thinning of the glacier surface which favored break-up.

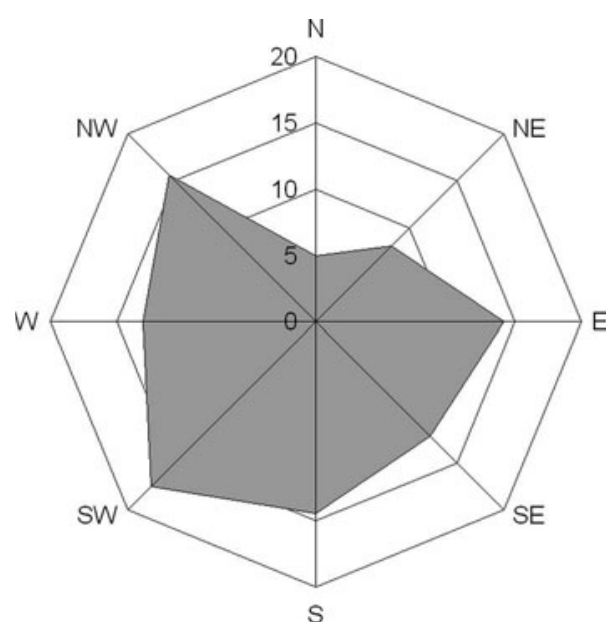

Fig. 4. Aspect frequency distribution of the 485 glaciers in spatial domain 1. Numbers represent the percent of glacier area in $22.5^{\circ}$ aspect bins. Glaciers in the Cordillera Blanca have a southwest preferred aspect. 


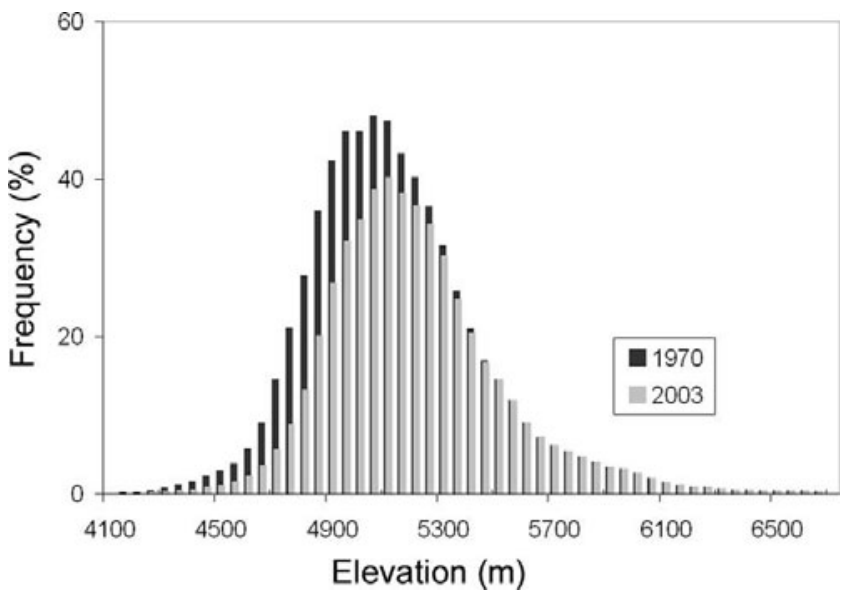

Fig. 5. Distribution of glacier area with elevation in 1970 (black bars) and 2003 (grey bars). The hypsographies are constructed from the 1970 DEM for the 1970 IGN glacier outlines and the 2003 SPOT glacier outlines. Most of the loss in glacier area occurred below $5400 \mathrm{~m}$; the shift of glacier ice to higher elevations is also notable.

The difference in glacier hypsographies corresponding to 1970 and 2003 glacier outlines (Fig. 5) shows the decrease in glacier area along with the shift of glacier ice to higher elevations. The largest loss in glacier area $\left(\sim 80 \mathrm{~km}^{2}\right)$ occurred between elevations of 4800 and $5100 \mathrm{~m}$, with little change in glacier extents above $5400 \mathrm{~m}$.

\section{Glacier-by-glacier comparison for spatial domain $\mathbf{2}$}

For the subset of 367 glaciers selected for detailed analysis, the loss in glacier area ranged from $90.9 \%$ to $1.3 \%$, with an average loss of $22.1 \%$ (Table 5). There was no statistically significant difference in glacier area changes between 1970 and 2003 for glaciers located on the western side $(-22.2 \%)$ vs those located on the eastern side $(-21.9 \%)$ of the Cordillera Blanca at the $95 \%$ confidence interval. On average, small glaciers $\left(<1 \mathrm{~km}^{2}\right)$ lost more of their area from 1970 to 2003 (Fig. 6). The non-linear relationship between glacier size and percent area loss is significant at the $95 \%$ confidence interval $(p<0.05)$. There is high variability in the percent area lost by small glaciers, ranging from $2 \%$ to $90 \%$ (Fig. 6). The wide range in the magnitude of glacier area changes for small glaciers $\left(<1 \mathrm{~km}^{2}\right)$ may be partly explained by factors such as (a) differences in the maximum elevation of glaciers relative to their ELAs, (b) the elevation of the mountain on which they are located and (c) the altitudinal range of the glaciers. First, we found a significant negative relationship between percent area change and the

Table 5. Glacier elevation and area changes from 1970 (IGN digital inventory) to 2003 (SPOT-derived glacier outlines) for the 367 selected glaciers in spatial domain 2

\begin{tabular}{lcccc}
\hline & $\begin{array}{c}\text { Number of } \\
\text { glaciers }\end{array}$ & Area change & $\begin{array}{c}\text { Median } Z \\
\text { change }\end{array}$ & $\begin{array}{c}\text { Terminus } Z \\
\text { change }\end{array}$ \\
& & $\%$ & $\mathrm{~m}$ & $\mathrm{~m}$ \\
\hline Eastern CB & 135 & -21.9 & +69.4 & +136.76 \\
Western CB & 232 & -22.2 & +63.2 & +99.4 \\
All glaciers & 367 & -22.1 & +65.6 & +113.4 \\
\hline
\end{tabular}

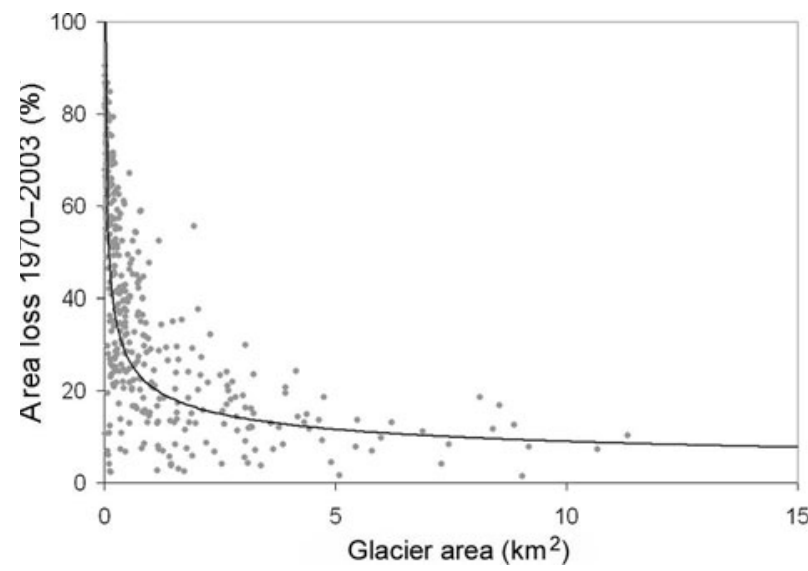

Fig. 6. Non-linear relationship between percent area loss and glacier size from 1970 to 2003 for the 367 glaciers included in spatial domain 2 (grey circles); curve fit using a second-order power function.

difference between the maximum elevation of the glacier and its median elevation. This indicates that glaciers with median elevations closer (in altitude) to their maximum elevations are losing more area. Second, regression analysis showed a significant negative relationship between the maximum elevation of the glacier (at the head) and the percent area loss $(p<0.05)$, indicating that glaciers located on lower summits are also losing more area. Third, we found a significant negative relationship $(p<0.05)$ between the change in area vs the altitudinal range of a glacier, calculated as maximum minus minimum elevation. This suggests that glaciers with a smaller altitudinal range are losing more of their area. Correlation analysis showed that small glaciers tend to have both smaller altitudinal ranges and median elevations closer to the glacier head $(r=0.7)$.

These statistical results support the idea that small glaciers with narrow altitudinal range are losing more of their area, also noted in other studies in the area (Kaser and Osmaston, 2002; Mark and Seltzer, 2005). This may be explained by the fact that a change in local climate may raise the ELA of those glaciers above their maximum elevation, putting the whole area of the glacier in the year-round ablation zone (Kaser and Osmaston, 2002). In contrast, larger glaciers have a very wide altitudinal range, with ELAs well below the maximum elevation at the glacier head.

We noted a difference in the area changes of clean glaciers vs glaciers with debris-covered tongues. Of the 367 glaciers selected for analysis, only 19 were covered by debris, comprising $0.8 \%$ of the area of spatial domain 2 . On average, these glaciers had a change of $13.3 \%$ in area, which is $8.7 \%$ less than the system as a whole. The remaining 348 clean glaciers lost on average $23.3 \%$ of their areas. The debris-covered glacier tongues appear to lose area at a slower rate than 'clean' glacier tongues. Thick debris on glacier tongues was shown to insulate the underlying ice and to prevent melting (Nakawo and Rana, 1999). However, the slower rate of area loss by debris-covered glaciers did not influence the overall calculation of glacial retreat because of the small area represented by debris cover.

Glacier termini in this subset area shifted upwards by $113 \mathrm{~m}$ on average. The rise in glacier terminus elevations was $38 \%$ larger $(137 \mathrm{~m})$ on the eastern side of the divide than on the western side $(99 \mathrm{~m})$. On average, median elevations 


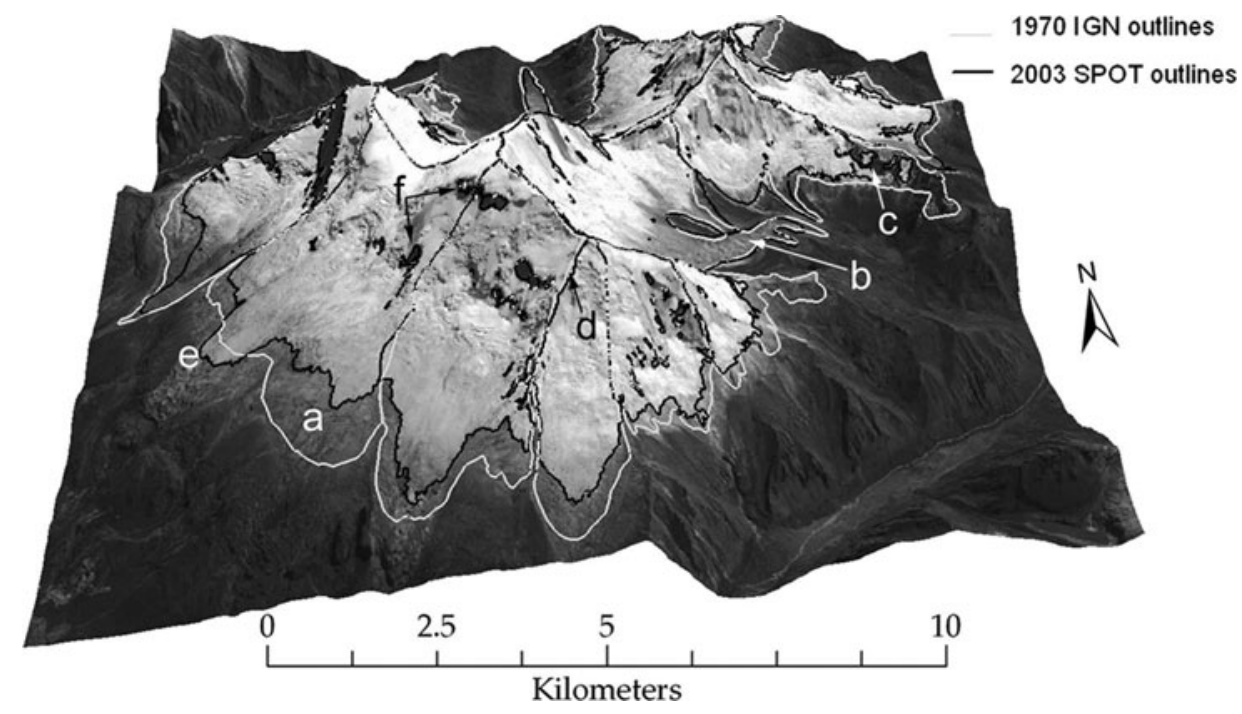

Fig. 7. Glacier change in the Huascarán-Chopicalqui massif from 1970 (black curves) to 2003 (light grey curves). The SPOT scene is shown as three-dimensional perspective using the 1970 topography. Labels point to: (a) retreat of glacier tongues; (b) debris-covered tongues; (c) the disintegration of glaciers; (d) differences in ice divides; (e) a digitizing error in the 1970 inventory, suggesting a false advance of the glacier terminus; and (f) internal rock outcrops subtracted from glacier area calculations.

increased by $66 \mathrm{~m}$, with $10 \%$ more on the eastern side $(69 \mathrm{~m})$ than on the western side $(63 \mathrm{~m})$ (Table 5). The differences in terminus and median elevation changes between the western and eastern sides may be climatedriven. Glaciers on the wetter eastern side extend to lower elevations due to the increased moisture by convection from the Amazon, which favors lower snowlines (Kaser and Georges, 1997). The greater increase in glacier terminus and median elevations on the wetter eastern side suggests that these glaciers may be more sensitive to climatic change.

The comparison of 2003 SPOT-derived outlines with the 1970 outlines for the Huascarán-Chopicalqui massif (Fig. 7) illustrates a few spatial patterns in the behavior of individual glaciers in the last three decades. We note (1) differential rates of retreat of glacier tongues, ranging from 100 to $800 \mathrm{~m}$, (2) the stagnation of the debris-covered tongues, (3) an increase in the number of glaciers from 18 to 26 from 1970 to 2003, indicating the disintegration of ice bodies into smaller parts, (4) slight differences in the ice divides between the two sets of outlines, and (5) digitizing errors in 1970 glacier outlines, pointing to an apparent advance in the Huascarán area. Debris-free Huascarán-Chopicalqui glaciers lost $18.67 \%$ of their area from 1970 to 2003, which is about $4 \%$ less than the retreat at the entire extent of spatial domain 1 . These glaciers have continued their recession at approximately the same rate as during the decades 1920-70, noted by Kaser and others (1996).

\section{Glacier area change for the entire mountain range (spatial domain 3)}

The overall factor of glacier recession for the area covered by spatial domain 1 was $516.1 \mathrm{~km}^{2} / 665.1 \mathrm{~km}^{2}=0.77$. Using this recession factor, we estimated the glacier area for the Pongos, Caullaraju, Rosco and Pelegatos mountain groups to be $53.5 \mathrm{~km}^{2}$. After adding these glaciers to the area in spatial domain 1, and applying a GIS 'buffer' method, we estimated the glacier area for the entire Cordillera Blanca to be $569.6 \pm 21 \mathrm{~km}^{2}$ in 2003 . The rate of change from 1970 to 2003 derived from this study is $-0.68 \% \mathrm{a}^{-1}$, which is consistent with recession trends documented in other studies in the same area (Kaser and others, 1990, 1996; Hasternath and Ames, 1995; Georges, 2004; Silverio and Jaquet, 2005) (Table 6; Fig. 8). The recession trends of Cordillera Blanca glaciers are also consistent with the behavior of other tropical glaciers in the last three decades: southern Peruvian AndesNevado Coropuna $\left(-0.7 \% \mathrm{a}^{-1}\right.$ from 1962 to 2000) (Racoviteanu and others, 2007); Qori Kalis glacier, eastern Peruvian Andes $\left(-0.6 \% \mathrm{a}^{-1}\right)$ (Thompson and others, 2006); Kilimanjaro, Tanzania ( $-1.15 \% \mathrm{a}^{-1}$ from 1970 to 1990); and Kenya $\left(-0.8 \% \mathrm{a}^{-1}\right.$ from 1963 to 1993) (Kaser, 1999). Rates of glacier loss were slightly lower at mid-latitudes in the same period: Tien Shan $\left(0.5 \% \mathrm{a}^{-1}\right.$ from 1977 to 2001) (Khromova and others, 2003); Swiss Alps (0.6\% a ${ }^{-1}$ from 1973 to 1999) (Kääb and others, 2002; Paul and others, 2004); and western India $\left(0.53 \% \mathrm{a}^{-1}\right.$ from 1962 to 2001) (Kulkarni and others, 2007) (Fig. 8). These results suggest that low-latitude glaciers may experience larger changes in area than mid-latitude glaciers.

\section{Temperature and precipitation trends, 1970-99}

Annual air temperature showed an upward trend at all three climate stations with a complete 30 year record (Fig. 9). The Mann-Kendall results show a significant increase in annual air temperature at all three sites for $\alpha=0.05$ (Table 1). In contrast to annual air temperatures, annual precipitation trends from two out of three climate stations in the Cordillera Blanca with a complete 30 year record (Fig. 10) have a negative trend, which is not significant at $\alpha=0.05$ (Table 1 ). There appears to be an elevational dependency on the rate of air-temperature increase, with air temperature increasing faster at lower elevations. The increase in air temperature at the lowest-elevation site $(3000 \mathrm{~m})$ of $0.092^{\circ} \mathrm{Ca}^{-1}$ was about three times the rate of air-temperature increase at the highest-elevation site $(4100 \mathrm{~m})$ of $0.034^{\circ} \mathrm{Ca}^{-1}$. Vuille and Bradley (2000) also point to an elevation dependency of airtemperature changes based on empirical data from the western side of the Andes, in agreement with our results. They found a warming trend (1939-98) which decreased linearly with altitude, ranging from $0.39^{\circ} \mathrm{C}(10 \mathrm{a})^{-1}$ at elevations less than $1000 \mathrm{~m}$ to $0.16^{\circ} \mathrm{C}(10 \mathrm{a})^{-1}$ at elevations greater than $4000 \mathrm{~m}$. Similar trends were noted in a recent 


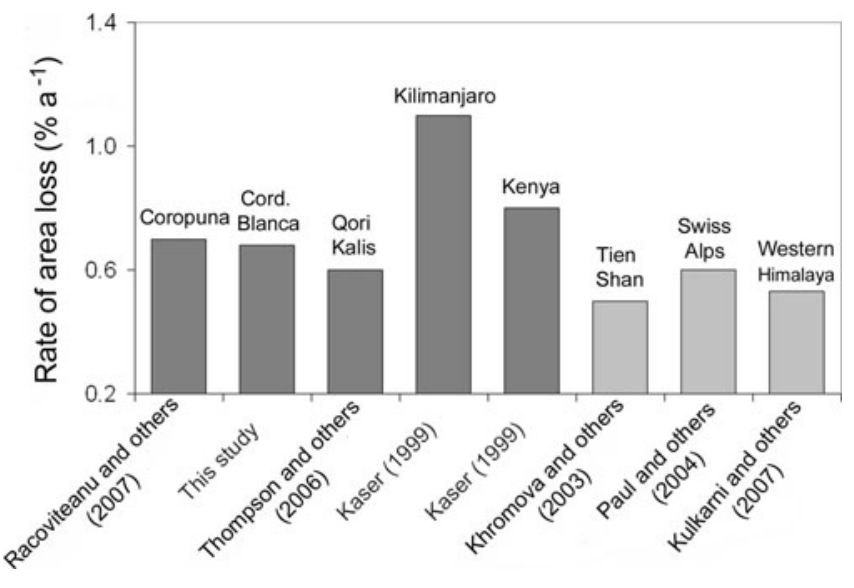

Fig. 8. Rates of area change in other glacierized areas of the world, expressed as $\% \mathrm{a}^{-1}$ based on various studies. Dark grey bars represent glaciers situated in the tropics; light grey bars represent mid-latitude glaciers.

study in western North America. Regonda and others (2005) suggested higher rates of increasing air temperature at lower elevations based on analysis of climate data from 1950 to 1999. Vuille and others (2003, p. 84) point out that the vertical structure of the warming trend in the tropics is different than what is observed in Tibet or the European Alps, where the warming is more pronounced at higher elevations. However, the high altitude warming in those regions is probably related to a decrease in spring snow cover, lower albedo values and a positive feedback on temperature (Liu and Chen, 2000)'. In contrast, these mechanisms are not important in the tropics due to a lack of thermal seasonality (Kaser and Georges, 1999).

These climate trends may help interpret our results of glacier area changes in the Cordillera Blanca in the last three decades. One possibility is that the pronounced upward shift of glaciers on the eastern side of the cordillera may be a reaction to larger temperature increases at lower elevations, coupled with a slight decrease in precipitation. Changes in air temperature may affect tropical glaciers in two ways: (1) by increasing ablation rates and (2) by shifting the position of the $0^{\circ} \mathrm{C}$ isotherm and thus determining whether precipitation falls as rain or snow at a particular point. For central Chile, Carrasco and others (2005) showed an increase in the elevation of the $0^{\circ} \mathrm{C}$ isotherm by as much as $122 \mathrm{~m}$ during the winter, and $200 \mathrm{~m}$ during the summer, from 1975 to 2001. Larger increases in air temperature at lower elevations result in a large upward shift of the $0^{\circ} \mathrm{C}$ isotherm, causing more precipitation to fall as rain than as snow at higher elevations. This diminishes the accumulation area and reduces the local albedo, which in turn increases the net solar radiation and promotes enhanced melting rates at lower elevations. This positive albedo feedback may partly explain the reaction of glaciers on the eastern side to climatic changes. However, we acknowledge that the response of individual glaciers to these fluctuations in climate variables is not uniform, and also depends on local topographic factors such as slope, aspect and glacier hypsometry, as well as thermal distribution of snow/ice and ice-flow dynamics.

Besides these local interactions, strong patterns of loss may be associated with larger atmospheric patterns related to El Niño-Southern Oscillation (ENSO) events (Wagnon and others, 2001; Francou and others, 2004). For example, higher ablation rates were observed on Glaciar Zongo (Wagnon and others, 1999) and Glaciar Chacaltaya (Wagnon and others, 2001) in Bolivia during the El Niño 1997-98 event. In a recent study, Vuille and others (2007) found the negative mass balance of glaciers in the Cordillera Blanca is correlated with dry warm phases of ENSO. During such events, higher temperatures affect mass balance either directly by decreasing the percent of precipitation falling as snow, or indirectly by lowering the surface albedo and increasing the amount of shortwave radiation absorbed (Francou and others, 2000). It is quite possible that the glacier retreat in the last three decades in the Cordillera Blanca may be a cumulative result of negative mass balance over prolonged periods, related to warm dry phases of ENSO.

Lastly, we need to consider the observed retreat of Cordillera Blanca glaciers in the context of longer-term climatic trends in the region. Kaser (1999) concluded that glaciers of the Cordillera Blanca have been in a state of general retreat following their maximum extent at the end of the Little Ice Age around the mid-19th century, with a large advance in the 1920s and a smaller advance in the 1970s. Since the 1970s, glaciers have started to retreat again at accelerated rates (Kaser, 1999). This continued retreat suggests that the small glaciers of the Cordillera Blanca have not yet adjusted to the warmer temperatures since the 1970s, and are still in disequilibrium with the present-day climate.

\section{Uncertainties and limitations}

Because our study integrates various data sources at different spatial and temporal resolutions, evaluating sources of uncertainty and their effect on glacier change estimations

Table 6. Comparison among different estimates of ice extent for the entire Cordillera Blanca (spatial domain 3) from previous studies. The rate of area change is given with respect to the 1970 glacier inventory (Ames and others, 1989)

\begin{tabular}{llcl}
\hline Year & Study & Area & Data source \\
& & $\mathrm{km}^{2}$ & \\
& & & \\
\hline 1970 & Ames and others (1989) & 723.3 & 1970 aerial photography \\
1970 & Georges (2004) & 658.6 & Re-evaluation of 1970 aerial photography \\
1986 & Silverio and Jaquet (2005) & $643 \pm 43$ & 1986 Landsat \\
$\sim 1990$ & Georges (2004) & 618.8 & $1987 / 1991$ SPOT XS \\
$\sim 1997$ & Morales-Arnao (1999) & 611 & $1995 / 1997$ Landsat \\
1997 & Silverio and Jaquet (2005) & $600 \pm 61$ & 1997 Landsat \\
2003 & This study & $569.6 \pm 21$ & 2003 SPOT5
\end{tabular}




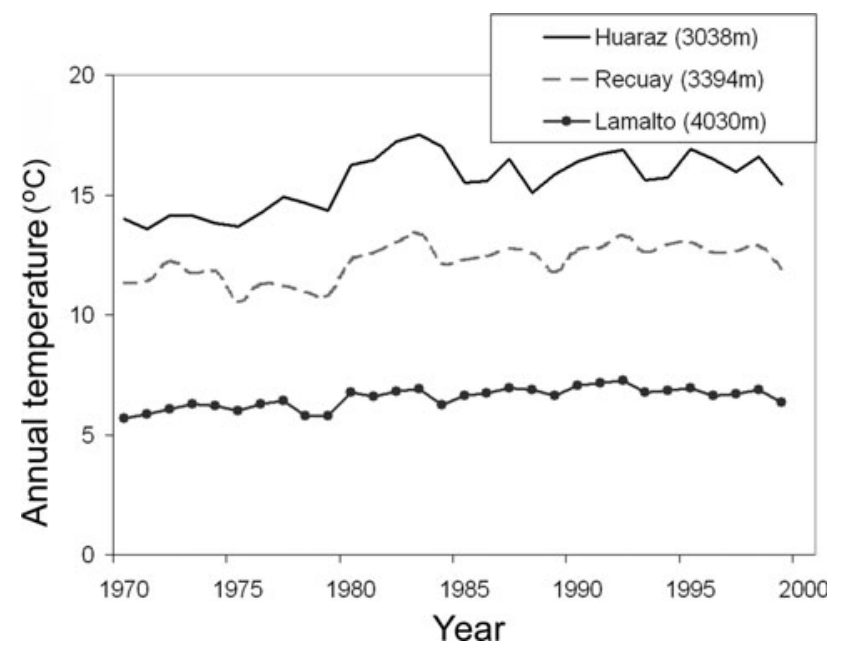

Fig. 9. Mean annual temperature trends from three climate stations on the western side of the Cordillera Blanca for the period 197099. There is an accentuated increase in temperature at lower elevations $(\sim 3000 \mathrm{~m})$ in the last three decades.

is crucial. Sources of uncertainty in this study arise from: (1) errors embedded in the various data sources used (remote sensing-derived data, 1970 topographic maps and aerial photography, GPS measurements and climate station data); (2) processing errors associated with DEM generation from 1970 topographic maps, glacier delineation algorithms, resolution manipulation, raster to version conversion, and misidentification of ice bodies; and (3) conceptual errors associated with defining a glacier and differences in delineating ice divides in various datasets.

Positional uncertainties in the 2003 glacier outlines from orthorectification of the SPOT5 imagery are minimal. The horizontal root-mean-square error $\left(\mathrm{RMSE}_{x, y}\right)$ from orthorectification was $<5 \mathrm{~m}$ with respect to GCPs, and is considered negligible. We estimate the accuracy of the glacier outlines derived from image classification to be one pixel $(10 \mathrm{~m})$, as cited in most accuracy studies (Congalton, 1991; Zhang and Goodchild, 2002). The overall error in glacier area, estimated using the GIS 'buffer' method, is $3.6 \%$, or $\pm 21 \mathrm{~km}^{2}$.

Other errors in SPOT5 data processing are associated with the precision of geographical coordinates (the number of bits used to store geographical coordinates); spurious polygons called 'sliver' polygons; atmospheric and topographic effects; and data smoothing during resampling. These are also considered minimal. Atmospheric effects are negligible. Topographic effects caused by differential solar illumination of the Earth's surface in the complex terrain of the Cordillera Blanca are minimized with the use of the NDSI classification method. Other sources of error in the SPOT5 imagery, including limitations of the sensor itself, such as the sensor's instantaneous field of view (IFOV), altitude, velocity and attitude (Dungan, 2002), point-spread function (PSF; Manslow and Nixon, 2002) and spectral mixing (Atkinson, 2004; Foody, 2004), are of unknown extent, but considered negligible.

We acknowledge that our estimates of glacier elevations are highly sensitive to the quality of the DEM used for analysis. Previous studies (Kääb and others, 2003; Berthier and others, 2006; Racoviteanu and others, 2007) have shown the difficulty of distinguishing between glacier

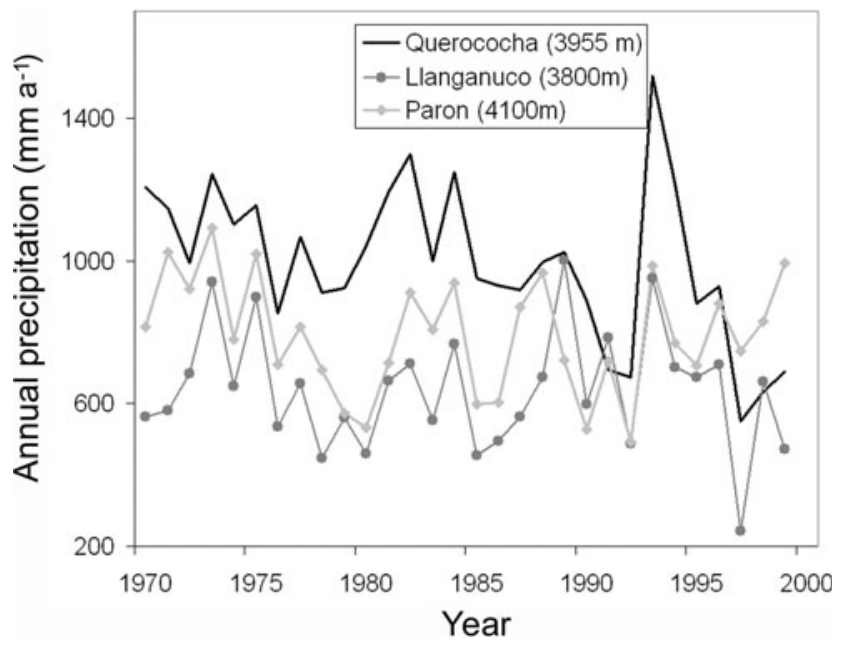

Fig. 10. Mean annual precipitation trends from three climate stations on the western side of the Cordillera Blanca for the period 1970-99. There is a slight decrease in precipitation at all elevations, with high variability in annual precipitation from year to year.

surface elevation changes and the bias present in DEMs constructed from various sources, including the Advanced Spaceborne Thermal Emission and Reflection Radiometer (ASTER) and Shuttle Radar Topography Mission (SRTM). In this study, we used a single set of elevations derived from 1970 topographic data to extract glacier parameters. This ignores potential changes in glacier elevations that may have occurred since the 1970s, but minimizes the bias introduced by using different elevation datasets.

However, the largest source of error in this study comes from measurement errors embedded in the 1970 glacier data derived from topographic maps and aerial photography, which affect the comparison with the SPOT-derived glacier areas. Errors in the 1970-derived DEM may be due to (1) difficulties in the stereoscopic process in the accumulation areas of glaciers due to lack of contrast in the aerial photos, resulting in misinterpretation of glacier elevations, (2) whether or not the aerial photographs were orthorectified, (3) digitizing errors, particularly in glacier areas covered by debris, and (4) the accuracy of the interpolation algorithm used to create a DEM. The horizontal accuracy of the topographic DEM is estimated to $12.5 \mathrm{~m}$, which is only $2.5 \%$ larger than one pixel size of the SPOT imagery $(10 \mathrm{~m})$, and its vertical accuracy is $18 \mathrm{~m}$. Errors embedded in processing of the 1970 aerial photographs are unknown, but some of them were discussed by Georges (2004). He reanalyzed the 1970 images of the Cordillera Blanca using land-based photos, and found the glacier area in 1970 to be $658.6 \mathrm{~km}^{2}$, instead of $723.3 \mathrm{~km}^{2}$ as reported by Ames and others (1989). This suggests that the glacierized area was overestimated by as much as $10 \%$ in the inventory of Ames and others (1989). For our study, this results in a difference of $7 \%$ in the estimate of glacier change from 1970 to 2003 depending on whether the glacier area from Ames and others (1989) or Georges (2004) is used as baseline.

Lastly, there are conceptual errors related to confusion over the definition of a glacier, and/or the lack of standardized methods for abstracting and representing a glacier in a GIS database. This poses issues related to: (1) how ice divides should be defined; (2) whether or not internal rocks should be included as part of area calculations; (3) whether 
perennial snowfields should be considered part of the glacier; (4) what threshold for surface area, if any, should be used for glacier delineation; (5) how fragmented glaciers should be treated; (6) whether steep rock walls that avalanche snow onto a glacier should be included as part of the glacier; and (7) whether 'inactive' bodies of ice above a bergschrund connected to a glacier should be considered as part of the glacier. Currently, there is no consensus within the glaciological community on these issues. For example, some previous inventories (e.g. Georges, 2004) excluded the inactive parts at the heads of glaciers, whereas our study included them. Furthermore, our SPOT ice divides, derived by semi-automatic methods, did not match perfectly the ice divides from the 1970 inventory. We also assumed no migration of ice divides. While at the mountain-range scale these inconsistencies seemed to cancel out, the area comparison on a glacier-by-glacier basis was more prone to uncertainty. This shows the need to establish standard processing protocols for deriving glacier change from various data sources, which is addressed by efforts within the framework of the GLIMS project.

\section{CONCLUSIONS AND FURTHER WORK}

We have combined geospatial analysis techniques with remote-sensing and field data to document spatial patterns of glacier changes in the Peruvian Cordillera Blanca from 1970 to 2003. Storing the glacier outlines in a GIS enabled us to perform spatial analyses at different scales, and to update glacier statistics for the entire mountain range. This is the first comprehensive geospatial glacier inventory for the Cordillera Blanca since 1970. We summarize as follows:

1. Glaciers of the Cordillera Blanca lost $22.4 \%$ of their area from 1970 to 2003, with no significant difference between glaciers on the eastern and western side of the divide;

2. Small low-lying glaciers, with a large proportion of their area in the ablation zone, lost ice at higher rates than larger glaciers;

3. Debris-covered glaciers lost a smaller proportion of their area than clean glaciers;

4. There is a notable shift in glacier ice to higher elevations, with more pronounced shifts on the eastern side of the cordillera

5. Mean temperature increases over the past three decades have been greater at lower elevations than at higher elevations, with little change in precipitation.

Further work is needed to use these multitemporal datasets, derived from various remote sensors, for glacier change detection and mass-balance applications. In particular, careful error evaluation and quantification of each data source used for change detection are critical. Inconsistencies among the various datasets, and the errors inherent in the data sources used by previous studies constitute the main source of uncertainty in our estimations of glacier change. Uncertainty and error propagation need to be better addressed in the context of glaciological studies using available GIS technologies detailed in recent studies (Burrough and McDonnell, 1998; Atkinson and Foody, 2002; Zhang and Goodchild, 2002; G.B.M. Heuvelink, http://www.ncgia.ucsb.edu/giscc/units/u098/u098.html). For future work, we suggest the following steps to minimize inconsistencies: (a) consistency in defining the inactive parts of the glaciers; (b) deriving ice divides automatically, to be used consistently for all subsequent glacier datasets; (c) using an agreed definition of what a 'glacier' includes (e.g. nunataks and supraglacial lakes); (d) deriving accurate elevation datasets from each time-step to quantify changes in glacier volume; and (e) developing robust algorithms for automatic mapping of debris-covered glaciers. Once these procedures are in place, further work can be undertaken towards using multitemporal glacier datasets for massbalance studies and estimations of future water resources.

\section{ACKNOWLEDGEMENTS}

We thank the Great Ice research unit of the Institut de Recherche pour le Développement, France, for providing access to SPOT satellite images, software and field support; the GLIMS project at the NSIDC for facilitating data transfer and providing input; the Peruvian National Meteorological and Hydrological Service (SENHAMI) for providing unpublished climate data; the Peruvian National Institute of Natural Resources (INRENA) Glaciology Unit (J. Gomez López and M. Zapata) for providing logistical support and help in the field data collection stage of the project; and the Niwot Ridge Long-Term Ecological Research (LTER) project funded by the US National Science Foundation, which provided computer and salary support. Reviews from D. Quincey and C. Huggel improved the quality of the paper.

\section{REFERENCES}

Aizen, V.B., V.A. Kuzmichenok, A.B. Surazakov and E.M. Aizen. 2007. Glacier changes in the Tien Shan as determined from topographic and remotely sensed data. Global Planet. Change, 56(3-4), 328-340.

Ames, A. and S. Hastenrath. 1996. Mass balance and flow of the Uruashraju glacier, Cordillera Blanca, Perú. Z. Gletscherkd. Glazialgeol., 32, 83-89.

Ames, A. and 6 others. 1989. Glacier inventory of Perú, Part 1. Huaraz, Peru, Hidrandina S.A.

Aniya, M., H. Sato, R. Naruse, P. Skvarca and G. Casassa. 1996. The use of satellite and airborne imagery to inventory outlet glaciers of the Southern Patagonia Icefield, South America. Photogramm. Eng. Remote Sens., 62(12), 1361-1369.

Atkinson, P.M. 2004. Resolution manipulation and sub-pixel mapping. In Van der Meer, F.D., ed. Remote sensing data analysis: including the spatial domain. Dordrecht, etc., Kluwer Academic Publishers.

Atkinson, P.M. and G.M. Foody. 2002. Uncertainty in remote sensing and GIS: fundamentals. In Atkinson, P.M., ed. Uncertainty in remote sensing and GIS. Chichester, etc., Wiley and Sons.

Berthier, E., Y. Arnaud, C. Vincent and F. Rémy. 2006. Biases of SRTM in high-mountain areas: implications for the monitoring of glacier volume changes. Geophys. Res. Lett., 33(8), L08502. (10.1029/2006GL025862.)

Berthier, E., Y. Arnaud, R. Kumar, S. Ahmad, P. Wagnon and P. Chevallier. 2007. Remote sensing estimates of glacier mass balances in the Himachal Pradesh (Western Himalaya, India). Remote Sens. Environ., 108(3), 327-338.

Bolch, T. 2007. Climate change and glacier retreat in northern Tien Shan (Kazahkstan/Kyrgyzstan) using remote sensing data. Global Planet. Change, 56(1-2), 1-12.

Burrough, P.A. and R.A. McDonnell. 1998. Principles of Geographical Information Systems. Second edition. Oxford, etc., Oxford University Press. 
Carrasco, J.F., G. Casassa and J. Quintana. 2005. Changes of the $0^{\circ} \mathrm{C}$ isotherm and the equilibrium line altitude in central Chile during the last quarter of the 20th century. Hydrol. Sci. J., $\mathbf{5 0}(6)$, 933-948.

Congalton, R.G. 1991. A review of assessing the accuracy of classifications of remotely sensed data. Remote Sens. Environ., 37(1), 35-46.

Del Río, S., R. Fraile, L. Herrero and A. Penas. 2007. Analysis of recent trends in mean maximum and minimum temperatures in a region of the NW of Spain (Castilla y León). Theor. Appl. Climatol., 90(1), 1-12.

Dozier, J. 1984. Snow reflectance from Landsat-4 Thematic Mapper. IEEE Trans. Geosci. Remote Sens., 22(3), 323-328.

Dungan, J.L. 2002. Toward a comprehensive view of uncertainty in remote sensing analysis. In Atkinson, P.M., ed. Uncertainty in remote sensing and GIS. Chichester, etc., Wiley and Sons.

Foody, G.M. 2004. Sub-pixel methods in remote sensing. In Van der Meer, F.D., ed. Remote sensing data analysis: including the spatial domain. Dordrecht, etc., Kluwer Academic Publishers.

Francou, B., E. Ramírez, B. Cáceres and J. Mendoza. 2000. Glacier evolution in the Tropical Andes during the last decades of the 20th century: Chacaltaya, Bolivia and Antizana, Ecuador. Ambio, 29(7), 416-422.

Francou, B., M. Vuille, V. Favier and B. Cáceres. 2004. New evidence for an ENSO impact on low-latitude glaciers: Antizana 15, Andes of Ecuador, $0^{\circ} 28^{\prime} \mathrm{S}$. J. Geophys. Res., 109(D18), D18106. (10.1029/2003JD004484.)

Georges, C. 2004. 20th century glacier fluctuations in the tropical Cordillera Blanca, Peru. Arct. Antarct. Alp. Res., 36(1), 100-107.

Hall, D.K., G.A. Riggs and V.V. Salomonson. 1995. Development of methods for mapping global snow cover using Moderate Resolution Imaging Spectroradiometer (MODIS) data. Remote Sens. Environ., 54(2), 127-140.

Hastenrath, S. and A. Ames. 1995. Recession of Yanamarey Glacier in Cordillera Blanca, Peru, during the 20th century. J. Glaciol., 41(137), 191-196.

Hoffman, M.J., A.G. Fountain and J.M. Achuff. 2007. Twentiethcentury variations in area of cirque glaciers and glacierets, Rocky Mountain National Park, Rocky Mountains, Colorado, USA. Ann. Glaciol., 46, 349-354.

Johnson, A.M. 1976. The climate of Peru, Bolivia and Ecuador. In Schwerdtfeger, W., ed. World survey of climatology. Amsterdam, etc., Elsevier, 147-218.

Kääb, A., F. Paul, M. Maisch, M. Hoelzle and W. Haeberli. 2002. The new remote-sensing-derived Swiss glacier inventory: II. First results. Ann. Glaciol., 34, 362-366.

Kääb, A. and 6 others. 2003. Glacier monitoring from ASTER imagery: accuracy and application. EARSeL eProc., 2(1), 43-53.

Kargel, J.S. and 16 others. 2005. Multispectral imaging contributions to global land ice measurements from space. Remote Sens. Environ., 99(1-2), 187-219.

Kaser, G. 1999. A review of the modern fluctuations of tropical glaciers. Global Planet. Change, 22(1-4), 93-103.

Kaser, G. and C. Georges. 1997. Changes of the equilibrium-line altitude in the tropical Cordillera Blanca, Peru, 1930-50, and their spatial variations. Ann. Glaciol., 24, 344-349.

Kaser, G. and C. Georges. 1999. On the mass balance of low latitude glaciers with particular consideration of the Peruvian Cordillera Blanca. Geogr. Ann., 81A(4), 643-651.

Kaser, G. and H. Osmaston. 2002. Tropical glaciers. Cambridge, etc., Cambridge University Press.

Kaser, G., A. Ames and M. Zamora. 1990. Glacier fluctuations and climate in the Cordillera Blanca, Peru. Ann. Glaciol., 14, 136-140.

Kaser, G., C. Georges and A. Ames. 1996. Modern glacier fluctuations in the Huascarán-Chopicalqui Massif of the Cordillera Blanca, Perú. Z. Gletscherkd. Glazialgeol., 32, Part 2, 1995, 91-99.

Kaser, G., I. Juen, C. Georges, J. Gomez and W. Tamayo. 2003. The impact of glaciers on the runoff and the reconstruction of mass balance history from hydrological data in the tropical Cordillera Blanca, Peru. J. Hydrol., 282(1-4), 130-144.

Khalsa, S.J.S., M.B. Dyurgerov, T. Khromova, B.H. Raup and R. Barry. 2004. Space-based mapping of glacier changes using ASTER and GIS tools: learning from Earth's shapes and colors. IEEE Trans. Geosci. Remote Sens., 42(10), $2177-2183$.

Khromova, T.E., M.B. Dyurgerov and R.G. Barry. 2003. Latetwentieth century changes in glacier extent in the Ak-shirak Range, Central Asia, determined from historical data and ASTER imagery. Geophys. Res. Lett., 30(16), 1863. (10.1029/ 2003GL017233.)

Khromova, T.E., G.B. Osipova, D.G. Tsvetkov, M.B. Dyurgerov and R.G. Barry. 2006. Changes in glacier extent in the eastern Pamir, Central Asia, determined from historical data and ASTER imagery. Remote Sens. Environ., 102(1-2), 24-32.

Kulkarni, A.V. and I.M. Bahuguna. 2002. Correspondence. Glacial retreat in the Baspa basin, Himalaya, monitored with satellite stereo data. J. Glaciol., 48(160), 171-172.

Kulkarni, A.V., B.P. Rathore, S. Mahajan and P. Mathur. 2005. Alarming retreat of Parbati glacier, Beas basin, Himachal Pradesh. Current Sci., 88(11), 1844-1850.

Kulkarni, A.V. and 6 others. 2007. Glacial retreat in Himalaya using Indian remote sensing satellite data. Current Sci., 92(1), 69-74.

Liu, X. and B. Chen. 2000. Climatic warming in the Tibetan Plateau during recent decades. Int. J. Climatol., 20(14), 1729-1742.

Manley, W.F. In press. Geospatial inventory and analysis of glaciers: a case study for the eastern Alaska Range. In Williams, R.S., Jr and J.G. Ferrigno, eds. Satellite image atlas of glaciers of the world. US Geol. Surv. Prof. Pap. 1386-K.

Manslow, J.F. and M.S. Nixon. 2002. On the ambiguity introduced by a remote sensor's PSF. In Atkinson, P.M., ed. Uncertainty in remote sensing and GIS. Chichester, etc., Wiley and Sons.

Mark, B.G. and G.O. Seltzer. 2005. Evaluation of recent glacier recession in the Cordillera Blanca, Peru (AD 1962-1999): spatial distribution of mass loss and climatic forcing. Quat. Sci. Rev., 24(20-21), 2265-2280.

Morales-Arnao, B. 1999. Glaciers of Peru. In Williams, R.S., Jr and J.G. Ferrigno, eds. Satellite image atlas of glaciers of the world. US Geol. Surv. Prof. Pap. 1386-I, 151-179.

Moser, G., C. Georges and H. Schimmer. 2000. Die neue Alpenvereinskarte Cordillera Blanca 1:100000. In Östereichischer Alpenverein, ed. Alpensvereinsjahrbuch 2001. Innsbruck, Östereichischer Alpenverein, 48-53.

Nakawo, M. and B. Rana. 1999. Estimate of ablation rate of glacier ice under a supraglacial debris layer. Geogr. Ann., 81A(4), 695-701.

Paul, F., A. Kääb, M. Maisch, T. Kellenberger and W. Haeberli. 2002. The new remote-sensing-derived Swiss glacier inventory. I. Methods. Ann. Glaciol., 34, 355-361.

Paul, F., A. Kääb, M. Maisch, T. Kellenberger and W. Haeberli. 2004. Rapid disintegration of Alpine glaciers observed with satellite data. Geophys. Res. Lett., 31(21), L21402. (10.1029/ 2004GL020816.)

Perkal, J. 1966. On the length of empirical curves. In Nystuen, J., ed. Discussion paper 10, Michigan Inter-University Community of Mathematical Geographers. Ann Arbor, MI, University of Michigan, 130-142.

Rabatel, A., J.-P. Dedieu and C. Vincent. 2005. Using remotesensing data to determine equilibrium-line altitude and massbalance time series: validation on three French glaciers, 19942002. J. Glaciol., 51(175), 539-546.

Racoviteanu, A., W.F. Manley, Y. Arnaud and M. Williams. 2007. Evaluating digital elevation models for glaciological applications: an example from Nevado Coropuna, Peruvian Andes. Global Planet. Change, 59(1-4), 110-125.

Regonda, S.K., B. Rajagopalan, M. Clark and J. Pitlick. 2005. Seasonal cycle shifts in hydroclimatology over the western United States. J. Climate, 18(2), 372-384. 
Silverio, W. and J.M. Jaquet. 2005. Glacial cover mapping (19871996) of the Cordillera Blanca (Peru) using satellite imagery. Remote Sens. Environ., 95(3), 342-350.

Surazakov, A.B. and V.B. Aizen. 2006. Estimating volume change of mountain glaciers using SRTM and map-based topographic data. IEEE Trans. Geosci. Remote Sens., 44(10), 2991-2995.

Thompson, L.G. and 8 others. 2006. Abrupt tropical climate change: past and present. Proc. Nat. Acad. Sci. USA (PNAS), 103(28), $10,536-10,543$

Toutin, T., R. Chénier and Y. Carbonneau. 2002. 3D models for high resolution images: examples with Quickbird, IKONOS and EROS. Int. Arch. Photogramm. Remote Sens., 34(4), 547-551.

Vuille, M. and R.S. Bradley. 2000. Mean annual temperature trends and their vertical structure in the tropical Andes. Geophys. Res. Lett., 27(23), 3885-3888.
Vuille, M., R.S. Bradley, M. Werner and F. Keimig. 2003. 20th Century climate change in the tropical Andes: observations and model results. Climatic Change, 59(1-2), 75-99.

Vuille, M., G. Kaser and I. Juen. 2007. Glacier mass balance variability in Cordillera Blanca, Peru and its relationship with climate and large-scale circulation. Global Planet. Change, 62(1-2), 14-28.

Wagnon, P., P. Ribstein, G. Kaser and P. Berton. 1999. Energy balance and runoff seasonality of a Bolivian glacier. Global Planet. Change, 22(1-4), 49-58.

Wagnon, P., P. Ribstein, B. Francou and J.E. Sicart. 2001. Anomalous heat and mass budget of Glaciar Zongo, Bolivia, during the 1997/98 El Niño year. J. Glaciol., 47(156), 21-28.

Zhang, J. and M.F. Goodchild. 2002. Uncertainty in geographical information. London, Taylor \& Francis.

MS received 4 November 2007 and accepted in revised form 17 March 2008 